International Journal of Environment, Agriculture and Biotechnology
Vol-6, Issue-6; Nov-Dec, 2021
JUAB
Journal Home Page Available: https://ijeab.com/
Journal DOI: $10.22161 /$ ijeab

\title{
Financial Analysis of Fishing Business using Jubi Catching Equipment in Bulutui Village, West Likupang District, North Minahasa Regency, North Sulawesi Province
}

\author{
Christian R. Dien*, Grace O. Tambani dan Fanny Silooy
}

Faculty of Fisheries and Marine Sciences Sam Ratulangi University Manado. Indonesia Corresponding Author

Received: 17 Sep 2021; Received in revised form: 30 Oct 2021; Accepted: 07 Nov 2021; Available online: 12 Nov 2021 (C)2021 The Author(s). Published by Infogain Publication. This is an open access article under the CC BY license (https://creativecommons.org/licenses/by/4.0/).

\begin{abstract}
Traditional fishing gear jubi or arrows are still widely used by fishing communities in Bulutui Village, West Likpang District. The existence of this fishing gear continues to survive amid advances in fishing technology and this fishing gear is passed down from generation to generation. This research on the Financial Analysis of fishing gear business has never been carried out even though the results of this analysis will greatly assist fishermen in managing and developing their fishing business professionally.

The purpose of this study in general, namely to examine the cost structure of the fishing business using jubi in Bulutui Village, while specifically this study aims to examine the financial analysis of the fishing business using jubi in Bulutui Village.

The method used in this research is a survey method. Data collection techniques by means of observation and filling out questionnaires. The sampling method is using the Simple Random method. In this study, 10 respondents were taken from a total population of 30 jubi fishermen in Bulutui Village.

The results of the financial analysis that have been carried out are obtained from the Total Cost obtained from Fixed Costs less Variable Costs amounting to Rp.115.913.900, Operating Profit obtained from Total Revenue minus Variable Costs amounting to Rp. 132,798,950, the total profit obtained from the total revenue is less, the variable cost is $R p$. 112,486,100, the sales BEP is Rp. 18,511,638 and unit BEP of 3,161 individuals. This analysis shows that fishing business with jubi fishing gear in Bulutui Village is feasible to be developed. Based on the results of this analysis, it answers the problems in this study why jubi fishermen are able to survive in the midst of advances in fishing technology today because they are still profitable and feasible to be developed.
\end{abstract}

Keywords — Financial Analysis, Jubi, Bulutui Fisherman.

\section{INTRODUCTION}

Fishermen are not only people who depend on catching fish in the sea, but also people who are involved in the process of catching fish at sea. Traditional fishermen are fishermen who use boats and simple equipment to go to sea such as boats and oars. In general, the so-called traditional fishermen are fishermen who utilize fishery resources with traditional fishing equipment, small business capital, and relatively simple fishing organizations.
Fishermen are very dependent on the season, during the fishing season the fishermen are very busy at sea and on the contrary during the lean season many are unemployed and what often happens is that when they return to fishing, they can buy expensive goods and when it is famine, their life is very bad. With such conditions, the decline of coastal communities/fishers in the abyss of poverty cannot be avoided. In this regard, it is necessary to have an effort to utilize natural resources towards a more optimal, selfsupporting and community productivity in order to create a 
socio-economic life that has an impact on job creation and increasing income and standard of living (Nurfiarini, 2003).

Fisheries are all fishing businesses, fish cultivation and management activities to marketing the results (Mubiyarto, 1994 in Zubair and Yasin, 2011). According to Hanafiah and Saefuddin (2000) in Zubair and Yasin (2011) that fishing business is an activity to catch or collect animals or plants that live in the sea to earn income by making certain sacrifices. Capture fisheries is the business of catching fish and other aquatic organisms in the wild (seas, rivers, lakes, and other water bodies). The life of aquatic organisms in the wild and their factors (biotic and abiotic) are not intentionally controlled by humans.

The coastal area is defined as a land area bordering the sea, the land boundary includes areas that are waterlogged or not that are still affected by marine processes such as tides, sea breezes and salt intrusion. Boundaries in the sea are areas that are affected by natural processes on land such as sedimentation and the flow of fresh water into the sea, as well as marine areas that are affected by human activities on land (Bengen, 2001).

Coastal communities are a group of people living in coastal areas who live together and fulfill their needs from resources in coastal areas. People who live in cities or coastal settlements have socio-economic characteristics that are closely related to economic resources from the sea area (Prianto, 2005). Likewise, types of livelihoods that utilize natural resources or environmental services in coastal areas such as fishermen, fish farmers, and owners or workers of the maritime industry.

Traditional fishermen are referred to as people who are engaged in the marine sector by using sailboats without a motor (Mulyadi 2005). With simple fishing gear, the area of operation becomes limited, only around coastal waters. In addition to the limited catch, with the simplicity of the fishing gear owned, in certain seasons there is no catch that can be obtained. So that income is not in line with expectations and interferes with the welfare of fishermen, especially traditional fishermen. This has an impact on welfare which is reflected in the lifestyle and priority level of the livelihood needs of fishing communities in coastal areas.

Traditional fishing gear jubi or arrows are still widely used by fishing communities, including fishermen in Bulutui Village, West Likupang District. The existence of this fishing gear continues to survive amid advances in fishing technology and this fishing gear is passed down from generation to generation. This research on the Financial Analysis of fishing gear business has never been carried out even though the results of this analysis will greatly assist fishermen in managing and developing their fishing business professionally. Therefore, this research is deemed necessary to be carried out.

\section{RESEARCH METHODS}

\subsection{Basic Method}

The method that will be used in this research is the survey method. According to Sugiyono (2013), the survey method is a method used to obtain data from certain places that are natural and not artificial.

\subsection{Data collection technique}

The population in this study was the jubi fishing community in Bulutui Village, amounting to 30 people. Sampling using the sampling method, which is taking part of the population to be used as a sample of 10 respondents.

The data collected in this study are primary data and secondary data. Primary data in this study were taken by means of observation and interviews guided by questionnaires. Secondary data is data collected through a second party, usually obtained from agencies engaged in data collection such as statistical centers and others (Arikunto, 2013). Secondary data in this study were obtained from the Bulutui Village government and related agencies. Data collection techniques that will be used in this study are as follows:

\section{Observation}

Observation activities include systematic recording of events, behaviors, objects seen and other things needed to support the research being conducted (Sarwono, 2009). Observations were made by looking directly at the research location.

\section{Questionnaire}

Sugiyono (2008) states that a questionnaire or questionnaire is a data collection technique that is carried out by giving a set of questions or written statements to respondents to answer. The questionnaire in this study was used as a guide in interviewing respondents to find out the Financial Analysis of Fishing Business with jubi or arrow fishing gear.

\subsection{Data analysis method}

Data analysis will be carried out using the following financial analysis formula:

\section{BEP}

BEP is a situation where a business does not make a profit but also does not suffer a business loss. From the management point of view, BEP's situation does not mean financial loss, it's just that in terms of time they lose 
because of the time during production (business) they do not get more income as business profits.

\section{R/C Ratio}

$\mathrm{R} / \mathrm{C}$ ratio is a value that shows the comparison between Business Revenue (Revenue $=\mathrm{R})$ and Total Cost $($ Cost $=$ C). Within the limits of the amount of $\mathrm{R} / \mathrm{C}$ value, it can be known whether a business is profitable or not. Broadly speaking, it can be understood that a business will benefit if the revenue is greater than the cost of the business.

\section{B/C Ratio}

$\mathrm{B} / \mathrm{C}$ ratio is a value that shows the comparison between Net Profit $($ Benefit $=\mathrm{B})$ and Total Cost $($ Cost $=\mathrm{C})$. Within the limits of the $\mathrm{B} / \mathrm{C}$ value, it can be seen whether a business is profitable or not

\section{Payback Period}

Payback period is the ability of a company to return all invested capital/investment. Payback Period is expressed in units of time, for example months or years. The payback period is used as one of the complementary considerations in analyzing the feasibility of a business, because from the payback period, the payback period can be known for the payback period of all investment capital. The shorter the payback period, the more feasible a business is, this also means that the greater the net profit earned by the company.

\section{RESULTS AND DISCUSSION}

\subsection{General Condition of Research Site}

Bulutui Village is one of the villages located in West Likupang District, North Minahasa Regency and is one of the coastal villages of 20 villages in West Likupang District. The majority of the tribes in Bulutui Village are the Bajo tribe. Bulutui village before being inhabited by the community, was originally a coastal area of Likupang overgrown with water bamboo wilderness known as "bulutui". The name Bulutui Village itself is taken from the name of the bamboo.

In general, the topography of Bulutui Village is an area of hills / highlands, lowlands and coastal areas as well as tropical and rainy climates.

Most of the settlements are built on water, and most of the people in Bulutui Village work as fishermen, so that the largest income for the community is from the fishery sector.

Overall, the total population in Bulutui Village is 640 people, consisting of 190 families with the details, men amounting to 331 people and women totaling 309 people.
Research on population can be seen from the following table1.

Table 1. Total Population in Bulutui Village, West Likupang District by Age Group

\begin{tabular}{|c|c|c|c|c|}
\hline \multirow{2}{*}{$\begin{array}{c}\text { Age } \\
\text { group(year) }\end{array}$} & \multicolumn{2}{|c|}{ Bulutui Village } & Number & $\begin{array}{c}\text { Percentage } \\
\text { of Souls }\end{array}$ \\
\cline { 2 - 3 }$(\boldsymbol{\%})$
\end{tabular}

Source: Bulutui Village Office, 2021

The age group of Bulutui Village residents is 31-40 years old and the least is 0-10 years old. From the village office sources, no clear information was obtained regarding the composition of the population over 41 years of age. Age is one of the factors that quite influence a person's work productivity, but in the arrow business (Jubi) age cannot determine the level of income and gain profits, in this study the age of respondents with an age range of 31 years to 40 years amounted to 5 respondents. This age range with the largest number of respondents indicates that a mature age and in a healthy body condition determines the success of a business using arrow fishing gear (Jubi). While respondents aged over 41 years amounted to 2 people, indicating that the age of someone who is getting older means that the physical condition is somewhat declining so that fishermen who try to catch jubi gear are in small numbers. For details, the age range of respondents can be seen in the following table 2 .

Table 2. Age Range of Respondents

\begin{tabular}{|l|c|c|c|}
\hline No & Age Structure & $\begin{array}{c}\text { Number } \\
\text { of Souls }\end{array}$ & $\begin{array}{c}\text { Percentage } \\
\%\end{array}$ \\
\hline 1. & $20-30$ & 3 & 30 \\
\hline 2. & $31-40$ & 5 & 50 \\
\hline 3. & $>41$ & 2 & 20 \\
\hline \multicolumn{2}{|c|}{ Total } & 10 & 100 \\
\hline
\end{tabular}

Source: Primary Data, 2021

\subsection{Education Level}

The results showed that the education level of the respondents was mostly 5 people or $50 \%$ with elementary school education, while the lowest was respondents with high school education amounting to 2 people or $20 \%$. The next level of education of respondents can be seen in the following table3. 
Table 3. Respondents Education Level

\begin{tabular}{|l|c|c|c|}
\hline No & Education Level & $\begin{array}{c}\text { Number } \\
\text { (people) }\end{array}$ & $\begin{array}{c}\text { Percentage } \\
\%\end{array}$ \\
\hline 1. & SD & 5 & 50 \\
\hline 2. & SLTP & 3 & 30 \\
\hline 3. & SLTA & 2 & 20 \\
\hline & Total & 6 & 100 \\
\hline
\end{tabular}

Source; Processed Primary Data, 2021

\subsection{Cost Structure of Jubi Capture Fishery Business}

\section{Investment Fee}

Investment costs are funds that are not directly consumed but rotate to generate new revenues (Mantjoro, 1996). Investment costs in the arrow fishing business (Jubi) are in the form of costs incurred to obtain investment goods in the form of boats, outboard engines, compressors, coolbars, arrow fishing gear (Jubi) and flashlights. In the following table you can see all the investment costs in the Arrow Capture (Jubi) fishery.
Table 4. Total Investment Cost

\begin{tabular}{|l|l|c|}
\hline No. & \multicolumn{1}{|c|}{ Description } & Price (Rp) \\
\hline 1. & Boat & 20.600 .000 \\
\hline 2. & Outboard Machine & 21.900 .000 \\
\hline 3. & Compressor & 4.650 .000 \\
\hline 4. & Coolbox & 445.000 \\
\hline 5. & Arrow (Jubi) & $\mathbf{7 0 . 7 0 0}$ \\
\hline 6. & Flashlight & 1.085 .000 \\
\hline \multicolumn{2}{|l|}{ Total Investment Cost } & 48.750 .700 \\
\hline
\end{tabular}

Source: Primary Data, 2021

Table 4 shows that the largest investment costs incurred for the purchase of outboard engines, amounting to Rp. $21,900,000$ of the total investment costs and the smallest costs for making arrow fishing gear (Jubi) of Rp. 70,700.

\section{Fixed Costs}

Fixed costs consist of boat maintenance costs, outboard engines, compressors, colboxes, fishing gear and depreciation costs. All fixed costs are borne by the boat owner. Care and maintenance is carried out every three months when not carrying out fishing operations at sea. Here are the fixed costs in jubi fishing business

Table 5. Total Fixed Costs Per Year

\begin{tabular}{|l|l|l|l|l|l|}
\hline NO & \multicolumn{1}{|c|}{ Description } & $\begin{array}{c}\text { Economic } \\
\text { Life }\end{array}$ & $\begin{array}{c}\text { Depreciation } \\
\text { Cost }\end{array}$ & $\begin{array}{c}\text { Maintenance } \\
\text { Cost }\end{array}$ & Amount \\
\hline 1 & Boat & 10 & 2.060 .000 & 500.000 & 2.560 .000 \\
\hline 2 & Outboard Machine & 5 & 4.380 .000 & 700.000 & 5.080 .000 \\
\hline 3 & Compressor & 5 & 930.000 & 400.000 & 1.330 .000 \\
\hline 4 & Coolbox & 2 & 222.500 & & \\
\hline 5 & Arrows (Jubi) & 2 & 35.350 & & \\
\hline 6 & Flashlights & 1 & 1.085 .000 & & \\
\hline \multicolumn{7}{|l|}{ Total Fixed Cost } & & & $\mathbf{1 0 . 3 1 2 . 8 5 0}$ \\
\hline
\end{tabular}

Source: Primary Data, 2021

\section{Variable Costs}

Variable costs are costs that are directly related to the fishing ground (fishing ground) and the length of time for fishing operations, namely the total operational costs of fishing. In the following table, it can be seen that the cost is not fixed once a trip.

Table 6. Total Variable Costs per Year

\begin{tabular}{|l|l|l|c|}
\hline \multicolumn{1}{|c|}{ NO } & Description & \multicolumn{1}{c|}{ Amout } & Price (Rp) \\
\hline 1. & Gasoline & 15 Liter x @Rp.10.00 x 22 x 10 & 33.000 .000 \\
\hline 2. & Oil & 1 Botol x @Rp.50.000 x 22 x 10 & 11.000 .000 \\
\hline 3. & Ice & 190 Balok x @Rp.1.000 x 22 x 10 & 41.800 .000 \\
\hline
\end{tabular}




\begin{tabular}{|l|l|l|c|}
\hline 4. & Battery & 1 Buah x @ Rp.10.000 x 22 x 10 & 2.200 .000 \\
\hline 5. & Cigarettes & 4 Bungkus x @ Rp.20.000 x 22 x 10 & 17.600 .000 \\
\hline 6. & Rubber & & $\mathbf{1 . 0 5 0}$ \\
\hline \multicolumn{2}{|l|}{ Total Variable Cost } & $\mathbf{1 0 5 . 6 0 1 . 0 5 0}$ \\
\hline
\end{tabular}

Source: Primary Data, 2021

\section{Gross Revenue/Total Revenue}

Gross income/total revenue is the total production result multiplied by the selling price of the production multiplied by the selling price of fish at the fish collector/buyer. The size of the gross income earned by fishermen is highly dependent on the number of catches. The following is a table of total revenue per year.

Table 7. Total Revenue

\begin{tabular}{|l|l|l|l|l|l|l|}
\hline \multirow{2}{*}{ No } & Description & \multicolumn{3}{|l|}{ Production (Kg) } & \multirow{2}{*}{$\begin{array}{c}\text { Price } \\
(\text { Rp) }\end{array}$} & $\begin{array}{c}\text { Total Revenue } \\
\text { (Rp) }\end{array}$ \\
\cline { 2 - 5 } & Catch & $\begin{array}{l}\text { Per } \\
\text { Trip }\end{array}$ & $\begin{array}{l}\text { Per } \\
\text { Month }\end{array}$ & $\begin{array}{l}\text { Per } \\
\text { Years }\end{array}$ & & \\
\hline 1. & black goropa fish & 5 & 80 & 800 & 30.000 & 24.000 .000 \\
\hline 2. & Sand Cooler Fish & 5 & 80 & 800 & 17.000 & 13.600 .000 \\
\hline 3. & Lolosi Fish & 7 & 112 & 1.120 & 20.000 & 22.400 .000 \\
\hline 4. & Octopus & 2 & 32 & 320 & 15.000 & 4.800 .000 \\
\hline 5. & Lucky & 5 & 80 & 800 & 40.000 & 32.000 .000 \\
\hline 6. & Parrotfish & 5 & 80 & 800 & 20.000 & 16.000 .000 \\
\hline 7. & Red Snapper & 10 & 160 & 1.600 & 60.000 & 96.000 .000 \\
\hline 8. & Blue Lobster & 1 & 16 & 160 & 300.000 & 9.600 .000 \\
\hline 9. & Bobara Fish & 5 & 80 & 800 & 25.000 & 20.000 .000 \\
\hline Total & & $\mathbf{4 5}$ & $\mathbf{7 2 0}$ & $\mathbf{7 . 2 0 0}$ & & $\mathbf{2 3 8 . 4 0 0 . 0 0 0}$ \\
\hline
\end{tabular}

Source: Primary Data, 2021

\section{Revenue (Operating Profit)}

Operating profit is the profit of the arrow fishing business (Jubi) which is the difference between the total gross income and variable costs. The following is a table of revenue from jubi fishing business.

Table 8. Total Revenue

\begin{tabular}{|l|l|l|}
\hline No & Description & Amount (Rp) \\
\hline 1. & Gross Income & 238.400 .000 \\
\hline 2. & Variable Cost & 105.601 .050 \\
\hline \multicolumn{2}{|l|}{ Operating Profit (OP) } & $\mathbf{1 3 2 . 7 9 8 . 9 5 0}$ \\
\hline
\end{tabular}

Source: Primary Data, 2021

\section{Total Profit ( )}

The total profit is the total revenue minus the total cost, can be seen in the following table 9 .
Table 9. Total Profit

\begin{tabular}{|l|l|l|}
\hline No & Description & Amount $($ Rp) \\
\hline 1 & Total Receipt & $\mathbf{2 3 8 . 4 0 0 . 0 0 0}$ \\
\hline 2 & Total Cost & $\mathbf{1 1 5 . 9 1 3 . 9 0 0}$ \\
\hline \multicolumn{2}{|l|}{ Total Profit $(\boldsymbol{\pi})$} & $\mathbf{1 2 2 . 4 8 6 . 1 0 0}$ \\
\hline
\end{tabular}

Source: Primary Data, 2021

\subsection{Financial Analysis}

To find out the advantages of catching fish with jubi fishing gear in Bulutui Village, it is necessary to identify all the costs incurred and the income received. The amount of investment, fixed costs (FC), variable costs (VC), total costs (TC) and total revenues (TR) can be seen from the following table. 
Table 10. Investment, $F C, V C, T C$, and TR

\begin{tabular}{|l|c|}
\hline Description & Average \\
\hline Investment & 48.750 .700 \\
\hline Fixed cost (FC) & 10.312 .850 \\
\hline Fixed cost (VC) & 105.601 .050 \\
\hline Total Cost (TC) & 115.913 .900 \\
\hline Total receipts (TR) & 238.400 .000 \\
\hline
\end{tabular}

Source: Primary Data, 2021

The financial analysis carried out is as follows:

\section{Total Cost (Total Cost)}

Total Cost (TC) is the total number of fixed costs and variable costs incurred by the company to produce a number of products in a certain period.

Table 11. Total Cost (TC)

\begin{tabular}{|l|l|lc|}
\hline No & Description & \multicolumn{2}{|c|}{ Cost } \\
\hline 1 & Fixed Cost & $\mathrm{Rp}$ & 10.312 .850 \\
\hline 2 & Variable Costs & $\mathrm{Rp}$ & 105.601 .050 \\
\hline \multicolumn{2}{|l|}{ Total Cost } & Rp & $\mathbf{1 1 5 . 9 1 3 . 9 0 0}$ \\
\hline
\end{tabular}

Source: Primary Data, 2021

Based on the table 11, it is known that the variable cost that is issued per year is Rp. 105,601,050 and fixed costs (Fix Cost) incurred amounting to Rp. 10,312,850.

\section{Revenue (Operating Profit/OP)}

Operating Profit (OP) is the profit of fishing business with jubi fishing gear which is the difference between all gross income and variable costs.

Table 12. Revenue (OP)

\begin{tabular}{|l|l|l|}
\hline No & \multicolumn{1}{|c|}{ Description } & \multicolumn{1}{c|}{ Total Cost } \\
\hline 1 & Admission Fee & Rp. 238.400 .000 \\
\hline 2 & Variable Costs & Rp. 105.601 .050 \\
\hline \multicolumn{2}{|l|}{ Operating Profit (OP) } & Rp. 132.798.950 \\
\hline
\end{tabular}

Source: Primary Data, 2021

Based on the table, Operating Profit Rp. 132.798.950,- is the profit earned and can be used for the next production cost.

\section{Total Profit/Net Profit}

The advantages of fishing with jubi fishing gear in Bulutui Village can be seen in table 13.

Table 13. Net Profit

\begin{tabular}{|l|l|c|}
\hline No & Description & Amount \\
\hline 1 & Total Revenue & Rp. 238.400 .000 \\
\hline 2 & Total Cost & Rp 115.913 .900 \\
\hline
\end{tabular}

ISSN: 2456-1878 (Int. J. Environ. Agric. Biotech.)

https://dx.doi.org/10.22161/ijeab.66.3

\begin{tabular}{|l|l|}
\hline Total Profit & Rp 112.486.100 \\
\hline
\end{tabular}

Source: Primary Data, 2021.

Net Profit or the total profit obtained in the fishing business with jubi in Bulutui Village is Rp. 112.486.100,-

\section{Benefit Cost Ratio (BCR)}

Benefit Cost Ratio (BCR) is an estimate of the expected benefits in the future or the ratio of revenues to all expenditures. If $\mathrm{BCR}>1$ then the business is feasible to run.

\section{$\mathrm{BCR}=\mathrm{TR} / \mathrm{TC}$

$$
=\text { Rp. } 238.400 .000,- \text { / Rp. } 115,913,900,-=2,056
$$

Based on the feasibility analysis of fishing with jubi in Bulutui Village, the $\mathrm{B} / \mathrm{C}$ value is 2.056. This ratio indicates that the fishing business with jubi in Bulutui Village is feasible to run, because the benefits of fishing with jubi are greater than the costs.

\section{Break Event Point}

Sales BEP $=\mathrm{FC} /(1-\mathrm{VC} / \mathrm{TR})$

$=(\operatorname{Rp} .10 .312 .850) /(1-(\operatorname{Rp} .105 .601 .050) /$

(Rp.238.400,000))

$=$ Rp.18,511,667,6

Unit $\mathrm{BEP}=($ Sales BEP $) /($ Unit Price $)$

$=18,511,667.6 / 58,555$

$=$ Rp.3.161,3298 Tails

Based on the results of the analysis obtained from BEP sales, it shows the Break event point (Break event point) of the fishing business with this jubi is Rp. 18,511,667.6 and BEP units of Rp. 3,161.3298 tails.

\section{CONCLUSION}

1. Based on the analysis of the feasibility of fishing with jubi in Bulutui Village, the Benefit cost ratio value is $2.056>1$, indicating that the fishing business with jubi in Bulutui Village is feasible, because the benefits of fishing with jubi are greater than the costs expenditure.

2. Based on the results of the analysis of Net Profit or the total profit obtained in the fishing business with jubi in Bulutui Village of Rp. 112.486.100,- answering the problem in this study, why jubi fishermen are able to survive in the midst of advances in fishing technology today, apparently because it is profitable and feasible to be developed.

\section{REFERENCES}

[1] Bengen. D. G. 2010. Sinopsis Ekosistem dan Sumberdaya Alam Pesisir dan Laut. 
[2] Pusat Kajian Sumberdaya Pesisir dan Lautan. Institut Pertanian Bogor.

[3] Faiza, 2011. Efektifitas dan Keberlanjutan Pengelolaan Daerah Perlindungan Laut Berbasis Masyarakat. Disertasi. Sekolah Pasca Sarjana. IPB. Bogor.

[4] Gabriella Selaindoong,2019. Analisis Finansial Usaha Budidaya Ikan Nila Pada Karamba Jaring Tancap Di Desa Eris Kabupaten Minahasa. Skripsi, FPIK.2019.

[5] Prianto, E. 2005. Proseding "Fenomena Ak tual Tema Dok toral Arsitektur dan Perkotaan". Semarang:Badan Penerbit Universitas Diponegoro.

[6] Riduwan. 2012. Metode \& Teknik Menyusun Proposal Penelitian. Bandung: Alfabeta

[7] Roscoe, 2010, dikutip dari Uma Sekaran, 2006, Metode Penelitian Bisnis, Salemba Empat, Jakarta.

[8] Sugiyono. 2013. Metode penelitian Administrasi.Bandung.ALFABETA. Sugiyono, (2008). Metode Penelitian Kunatitatif Kualitatif dan R\&D. Bandung Alfabeta

[9] Sugiyono. 2013. Metode Penelitian Kuantitatif, Kualitatif, dan R\&D. Bandung: CV Alfabeta

[10] Subejo dan Supriyanto. 2005. Kerangka Pemberdayaan Masyarakat Pedesaan Menuju Pembangunan Yang Berkelanjutan. Jurnal Ilmu-Ilmu Pertanian.Vol. 1, No. 1. Juli 2005 Hal 17-32. 